\title{
EVALUASI KINERJA VIDEO STREAMING MPEG DASH MENGGUNAKAN PROTOKOL TRANSPORT MULTIPATH TCP
}

\author{
Dany Primanita Kartikasari ${ }^{1}$, Tohari Ahmad $^{2}$, Waskitho Wibisono ${ }^{3}$ \\ Universitas Brawijaya $^{1}$, Institut Teknologi Sepuluh Nopember ${ }^{2,3}$ \\ Email: dany.jalin@ub.ac.id ${ }^{1}$, tohari@if.its.ac.id ${ }^{2}$,waswib@if.its.ac.id ${ }^{3}$
}

\begin{abstract}
ABSTRAK
Tulisan ini menyampaikan hasil penelitian tentang efek penggunaan Multipath TCP sebagai protokol transport dalam menayangkan video streaming adaptif menggunakan MPEG DASH. Penelitian ini menguji efek penerapan mekanisme congestion control OLIA dengan penjadwal default pada video streaming, untuk dibandingkan dengan penayangan video streaming . Dari hasil penelitian didapatkan bahwa untuk kondisi jaringan yang stabil, TCP memberikan hasil yang lebih baik serta waktu unduh yang lebih kecil dibandingkan dengan MPTCP. Namun demikian dalam kondisi bandwidth yang berfluktuasi dan berbentuk anak tangga, MPTCP memberikan performa yang lebih baik dalam hal pengisian buffer dan dalam parameter waktu unduh.
\end{abstract}

Kata Kunci:MPTCP, MPEG-DASH, Video Streaming, Kualitas Video

\begin{abstract}
This paper describe an empirical studi about the impact of Multipath TCP implementation for adaptive video streaming using MPEG DASH. For experiment scenario combining two types congestion control mechanism and two scheduler methods. As the result, DASH video with MPTCP performed better than other video with TCP, especially for unstable network condition. DASH video with MPTCP has buffer occupancy better and also shorter time to download each video segment.
\end{abstract}

Keywords:MPTCP, MPEG-DASH, Video Streaming, Kualitas Video

\section{Pendahuluan}

Saat ini video streaming merupakan salah satu aplikasi melalui Internet yang menjadi aplikasi paling digemari. Menurut Cisco Visual Networking Index, pada tahun 2020 trafik video akan menempati 82 persen dari keseluruhan trafik yang beredar di Internet Global. [1]Teknologi perangkat dan Internet sendiri terus berkembang mengikuti kebutuhan layanan yang diinginkan penggunanya. Dalam dekade terakhir ini, hampir seluruh perangkat yang diproduksi dan dipasarkan sudah dilengkapi dengan multi kartu jaringan. Namun demikian, keberadaan multikartu ini belum dapat dimanfaatkan secara optimal, karena dalam mekanisme koneksi Internet yang ada saat ini, hanya ada satu kartu aktif yang dapat membentuk koneksi dengan perangkat tujuannya.
Penelitian pemanfaatan perangkat multihoming ini terus berkembang. Protokol transport pertama yang dikembangkan adalah Stream Control Transport Protocol (SCTP) [2] namun sulit untuk diimplementasikan karena perubahan yang harus diterapkan pada infrastruktur Internet begitu banyak. Sampai kemudian pada tahun 2011 diperkenalkan konsep Multipath TCP sebagai penambahan fungsi dan mekanisme dari protokol transport TCP. [3]

Sementara itu video streaming juga mengalami perkembangan yang sangat signifikan. Saat ini, video streaming dijalankan dengan mekanisme adaptif yang mampu beradaptasi dengan kondisi jaringan pada Client sehingga kualitasnya 
dapat menyesuaikan ketersediaan sumberdaya yang ada.

Tulisan ini menggambarkan efek dari implementasi protokol transport Multipath TCP pada video streaming adaptif menggunakan DASH. Dengan tujuan untuk memberikan gambaran mengenai keuntungan memenfaatkan multi jalur yang dimiliki oleh perangkat. Kontribusi dari tulisan ini adalah untuk menganalisis kinerja video streaming menggunakan DASH saat mempergunakan multijalur dengan memanfaatkan multipath TCP sebagai protokol transport. Untuk selanjutnya, penulisan akan disusun dalam urutan komposisi seperti dijelaskan berikut ini. Bagian dua akan menyampaikan penjelasan singkat mengenai Multipath TCP. Bagian tiga mengulas uraian singkat mengenai MPEG DASH. Kemudian dilanjutkan ke bagian empat mengenai metodologi penelitian. Bagian lima menjabarkan hasil pengujian dan diskusi. Bagian kesimpulan menyampaikan tentang kesimpulan dan potensi pengembangan.

\section{Multipath TCP}

Multipath TCP merupakan pengembangan dari TCP reguler yang dikemukakan oleh MPTCP working group bentukan Internet Engineering Task Force (IETF) sejak tahun 2009. MPTCP memberikan kemampuan untuk melayani aplikasi dengan protokol TCP reguler yang telah diterapkan saat ini, juga dirancang untuk mendukung perangkat multihome, memberikan reliabilitas end-to-end serta keamanannya. Kesepakatan multipath TCP dituangkan dalam RFC 6182 [4] dan RFC 6824 [5].

Multipath TCP pada prinsipnya berbeda dengan multipath routing. Pada Multipath TCP, aliran data yang dipisahkan sejak meninggalkan host pengirim. Aliran ini mengikuti pola routing yang ditentukan oleh provider jaringan. Ilustrasi skenario untuk Multipath TCP digambarkan pada Gambar
2.1. Dimana terdapat dua host yang saling berkomunikasi satu sama lain. Kedua host A dan B ini memiliki multi-interface dan multi-alamat yang memberikan koneksi ke Internet secara terpisah. Skenario ini dapat bertambah jumlah alamatnya antar host.

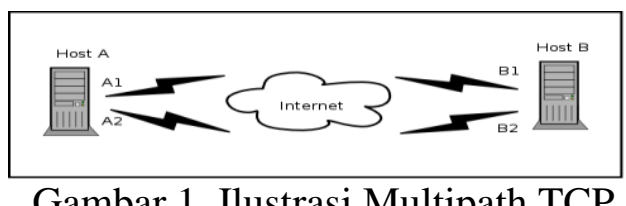

Gambar 1. Ilustrasi Multipath TCP

Dalam RFC 6356 [6] dinyatakan bahwa tujuan dari penggunaan Multipath TCP adalah:

a. Meningkatkan throughput:

b. Meningkatkan ketahanan

c. Menyeimbangkan kongesti

Multipath TCP bekerja pada layer transport dan merupakan fitur tambahan dari TCP standar seperti digambarkan pada Gambar 2.
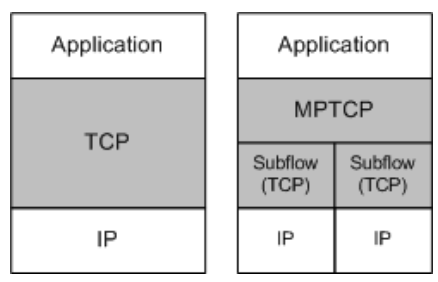

\section{Gambar2 . TCP dan MPTCP Protocol Stack}

Untuk membentuk koneksi dengan Multipath TCP dilakukan seperti halnya membentuk koneksi TCP reguler. Dengan mempergunakan three-way-handshake, Host A akan membentuk hubungan TCP dengan Host B. Namun jika pada kedua host mendukung protokol MPTCP, maka akan diinisiasi pembentukan subflow. Untuk kemudian alamat ke dua sampai ken akan dikenali sebagai subflow dari Host A, dan akan digunakan dalam proses pertukaran data antar Host. Proses inisiasi koneksi MPTCP dengan subflow ditampilkan pada Gambar 3. 


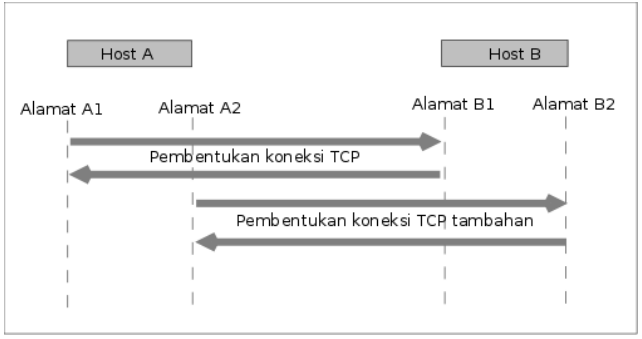

Gambar 3. Inisiasi koneksi MPTCP

Penjadwal MPTCP merupakan salah satu faktor yang mempengaruhi kinerja MPTCP. Untuk mendapatkan keuntungan dari menggunakan MPTCP, protokol ini harus mampu menentukan jalur logika yang akan dilewati oleh paket. Penjadwal bertugas untuk memutuskan bagaimana data akan didistribusikan pada jalur-jalur yang tersedia, sekaligus menangani pengiriman ulang melalui jalur yang berbeda bila diperlukan. Proses penjadwalan pada MPTCP terjadi jika terdapat lebih dari satu subflow dalam kondisi terbentuk. Ketentuan yang diberlakukan pada penjadwal adalah mencoba mengisi semua subflow. Kesalahan penjadwal dapat mengakibatkan masalahhead-of-line blocking atau pembatasan receive-window sehingga mempengaruhi kinerja MPTCP. Sementara itu, terdapat metode penjadwalan lain yang mungkin dimplementasikan pada kernel MPTCP. Salah satunya yang disampaikan dalam [3]adalah penjadwal round robin. Penjadwal round robin bekerja dengan memilih satu cabang aliran yang tersedia menurut algoritma round robin. Keuntungan menggunakan penjadwal ini adalah dapat menjamin kapasitas semua jalur dimanfaatkan dengan baik dan trafik terdistribusi dengan merata. Namun penjadwal ini mungkin akan mengalami masalah untuk mengirimkan data bulk. Paket akan dijadwalkan sesegera mungkin pada tiap congestion window di setiap subflow. Hal ini dikenal dengan efek ackclock.
Multipath TCP dirancang dengan algoritma pengendali kongesti yang berbeda dari reguler TCP. Pengendali kongesti untuk MPTCP diajukan dan disepakati dalam RFC6356. Dengan mengembangkan dari pengendali kongesti RENO, pada mekanisme ini menggandengkan algoritma pengendali kongesti pada cabang aliran yang berbeda dengan menghubungkan fungsi dan mengendalikan aliran multijalur dengan dinamis. Algoritma ini tetap mengacu pada mekanisme dalam TCP reguler untuk mendeteksi paket yang digagalkan dan mekanisme pengiriman ulang untuk data yang gagal dikirimkan. (Handley dkk., 2011)

Opportunistic Linked Increases Algorithm (OLIA) (Khalili dkk., 2013) merupakan algoritma pengendali kongesti berbasis window. Algoritma ini memasangkan peningkatan congestion window dan menggunakan perilaku TCP saat terjadi paket yang hilang. OLIA dipublikasikan setelah berhasil diimplementasikan pada sistem operasi Linux kernel 3.0.0. Algoritma ini hanya memperbaiki bagian fase menghindari kongesti pada TCP. Sedangkan algoritma fast retransmit dan algoritma fast recovery mengikuti TCP reguler. OLIA juga menggunakan mekanisme slow start seperti TCP, namun nilai ssthresh bernilai 1 MSS jika terbentuk multi jalur. JIka menggunakan jalur tunggal maka nilai ssthresh menjadi 2 MSS.

\section{Dynamic Adaptive Streaming over HTTP (DASH)}

Salah satu standar layanan multimedia melalui Internet adalah Dynamic Adaptive Streaming over HTTP (DASH). Standar ini dibentuk oleh ISO/IEC MPEG untuk memenuhi kebutuhan standar universal yang dapat bekerja pada infrastruktur Internet yang telah dipergunakan saat ini dan mengirimkan layanan video berkualitas tinggi yang dapat dinikmati pemirsanya. DASH merupakan 
penyesuaian dari HTTP streaming klasik dengan menambahkan kemampuan untuk mengganti level kualitas video yang cocok dengan ketersediaan sumberdaya jaringan saat itu. Video akan dibagi menjadi fragmen-fragmen kecil sesuai dengan ukuran GOP-nya (Group of Pictures). Ilustrasi mekanisme streaming video adaptif ditunjukkan dalam Gambar 4.

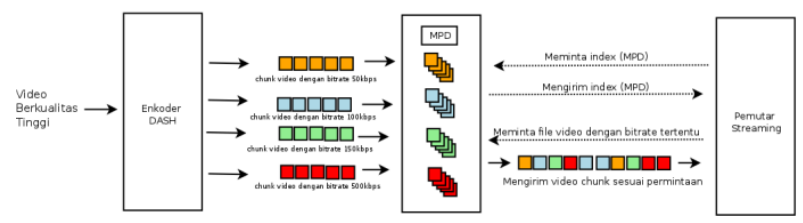

Gambar 4. Ilustrasi Adaptif Streaming

Pada DASH, klien dapat meminta dan menerima segmen-segmen konten multimedia dengan ukuran kecil yang disebut chunk. Chunk dibuat ntuk menyesuaikan media bitrate terhadap kondisi bandwidth jaringan, DASH memungkinkan klien untuk meminta segmen media dengan representasi yang berbeda dengan media bitrate spesifik. Ketika sudah terbentuk koneksi dengan server, Client akan meminta file MPD sebagai informasi mengenai video yang akan di unduh. File MPD ini akan diolah oleh plugin DASH. Sementara itu, algoritma adaptasi akan bekerja disisi Client dengan mengolah data transaksi pengunduhan file MPD tadi sebagai dasar perhitungan bandwidth dan sumber daya yang tersedia. Dengan mengambil hasil olahan dari algoritma adaptasi yang diterapkan pada plugin, pemutar akan meminta segmen video yang dibutuhkan dengan menyesuaikan kondisi hasil pengolahan algoritma tadi dengan informasi yang tercakup dalam MPD. Dalam hal ini informasi yang diambil adalah menyesuaikan bitrate encoding dari segmen yang akan di unduh dengan kondisi jaringan yang terakhir diperbaharui. Kemudian server akan mengirimkan segmen yang diminta client. Demikian selanjutnya, algoritma adaptasi akan bekerja memperhitungkan kondisi jaringan dan sumberdaya yang ada, untuk kemudian meminta segmen video yang berikutnya. Apabila terjadi perubahan signifikan pada kondisi jaringan dan menjadi lebih buruk dari sebelumnya, maka bitrate segmen video akan dikurangi ke level yang lebih rendah. Namun bila kondisi membaik, maka permintaan segmen selanjutnya dapat ditingkatkan ke level yang lebih tinggi. Ilustrasi MPD ditampilkan pada Gambar 5.
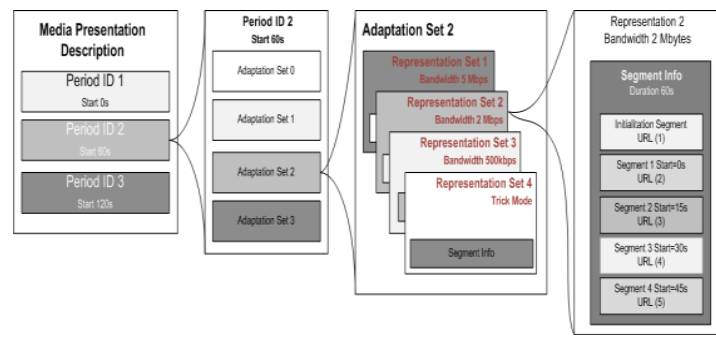

Gambar 5. Media Presentation Description (MPD)

\section{Metodologi Penelitian}

Pada bagian ini, kami akan menggambarkan metodologi dan langkahlangkah yang kami lakukan dalam melaksanakan penelitian serta menjelaskan metrik yang kami gunakan.

\subsection{Konfigurasi Testbed}

Kami menggunakan beberapa konfigurasi infrastruktur dalam menguji penelitian ini. Konfigurasi yang pertama ditunjukkan dalam Gambar 6. Konfigurasi infrastruktur ini digunakan untuk menguji kinerja MPEG DASH menggunakan koneksi tunggal dengan protokol transport TCP reguler.

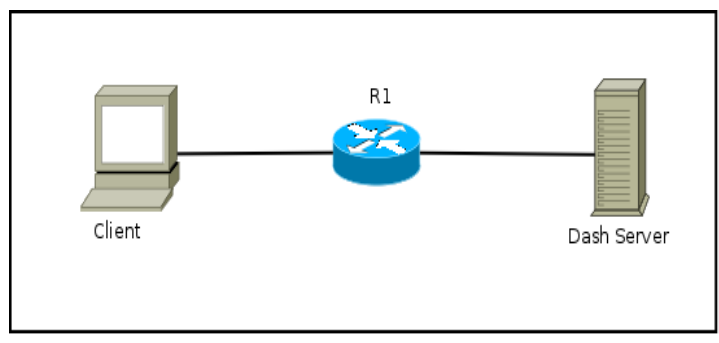

Gambar 6. Konfigurasi Infrastruktur 1 
Konfigurasi infrastruktur kedua ditunjukkan dalam Gambar 7. Konfigurasi ini menggunakan dua jalur jaringan, dengan protokol transport Multipath TCP.

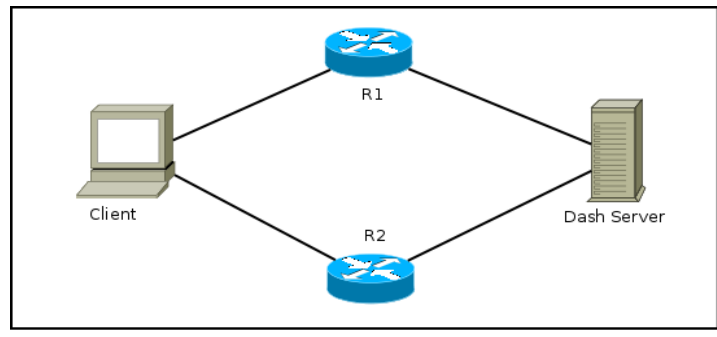

Gambar 7. Konfigurasi Infrastruktur 2

Untuk menguji efek penggunaan multijalur, digunakan konfigurasi infrastruktur 3. Konfigurasi ini menggunakan tiga jalur jaringan dengan protokol Multipath TCP. Konfigurasi infrastruktur 3 ditunjukkan dalam Gambar 8.

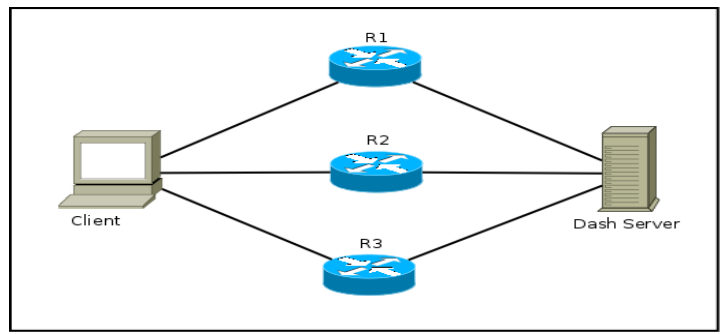

Gambar 8. Konfigurasi Infrastruktur 3

Untuk pengujian, kami menggunakan video Big Buck Bunny [7][8]mengacu pada penelitian kinerja DASH yang telah dilakukan dalam beberapa penelitian yang lain. Dalam tulisan ini, kami mempergunakan dataset dengan ukuran potongan video 1 detik. Keseluruhan potongan ini terdiri dari 599 potongan dengan ukuran file bervariasi. Dataset ini menyediakan 19 level representasi. Kami menggunakan VLC [9] sebagai pemutar video opensource yang dilengkapi dengan plugin DASH [6].Pemutar ini dipasang pada mesin virtual yang bertindak sebagai Client dan berpasangan dengan Apache Web server di sisi Server yang di bangun pada testbed mesin VirtualBox [11] dengan dikendalikan menggunakan
Vagrant [12]. Kedua mesin bekerja menggunakan sistem operasi Debian Linux 7 wheezy dengan dilengkapi kernel MPTCP yang dapat diunduh di [13] . Untuk mensimulasikan kondisi jaringan antara Client dan server, kami menggunakan wondershaper sebagai aplikasi bandwidth limiter.

\subsection{Metrik kinerja}

Kami menggunakan beberapa metrik dalam pengujian, yang terbagi dalam metrik MPEG DASH dan metrik MPTCP. Metrik MPEG DASH digunakan untuk mengevaluasi kinerja video streaming dari sisi aplikasi. Metrik yang dipergunakan adalah pengisian buffer, waktu pengisian buffer minimal, perubahan level kualitas dan waktu unduh segmen. Sedangkan metrik untuk MPTCP digunakan untuk mengevaluasi kinerja video streaming dari sisi kondisi jaringannya. Metrik untuk mengevaluasi penggunaan MPTCP adalah throughput, utilisasi link serta jumlah retransmisi.

\section{Hasil dan Diskusi}

Pemutaran video streaming MPEG DASH diujikan pada seluruh konfigurasi topologi menggunakan tiga skenario simulasi jaringan. Ketiga skenario ini merujuk pada skenario yang dipergunakan dalam [14]. Kami menguji bagaimana kualitas video streaming saat menggunakan satu kartu jaringan dengan protokol transport TCP, bila dibandingkan dengan kualitas video streaming adaptif saat mengaktifkan dua dan tiga kartu jaringan dengan protokol transport Multipath TCP. Kami juga membandingkan hasil saat menggunakan pengendali kongesti CUBIC dan OLIA. Dimana CUBIC bekerja dengan mekanisme TCP tunggal yang berinteraksi secara paralel. Sedangkan OLIA dirancang menggunakan mekanisme coupled yang juga memperhitungkan faktor besaran congestion window.Selain itu, kami menguji implementasi penjadwal default 
dengan penjadwal round robin. Pengujian dengan skenario ini akan menuntun pada kesimpulan untuk menjawab rumusan masalah nomor 1. Apakah pengaruh penerapan multipath TCP terhadap video streaming adaptif yang diputar.

\subsection{Skenario 1 menggunakan bandwidth stabil}

Dalam skenario ini, kondisi bandwidth tersedia pada jaringan bersifat stabil, tanpa gangguan sama sekali. Dari hasil pemutaran video streaming menggunakan skenario stabil seperti skenario 1 ini, penggunaan TCP tidak kalah performanya dibandingkan dengan video yang diputar menggunakan MPTCP.

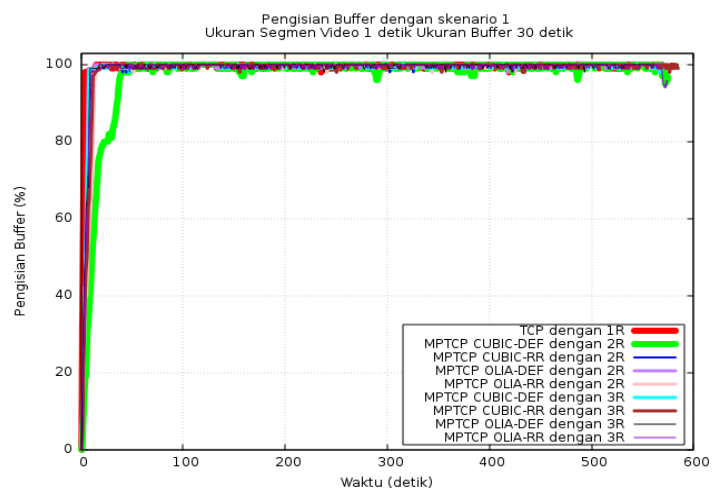

Gambar 9. Pengisian Buffer dengan skenario 1

Dengan menggunakan kondisi jaringan yang stabil, video streaming menggunakan satu, dua ataupun tiga jalur tidak mengalami perbedaan yang cukup berarti dalam mengisi buffer aplikasi. Seluruh percobaan dengan skenario 1 menghasilkan pengisian buffer yang relatif sama, tidak ada kondisi ekstrem yang terjadi. Hal ini disebabkan asupan paket data pada buffer berlangsung dengan baik, meskipun terjadi beberapa kejadian retransmisi, secara umum, tidak ada paket hilang dengan jumlah yang signifikan.

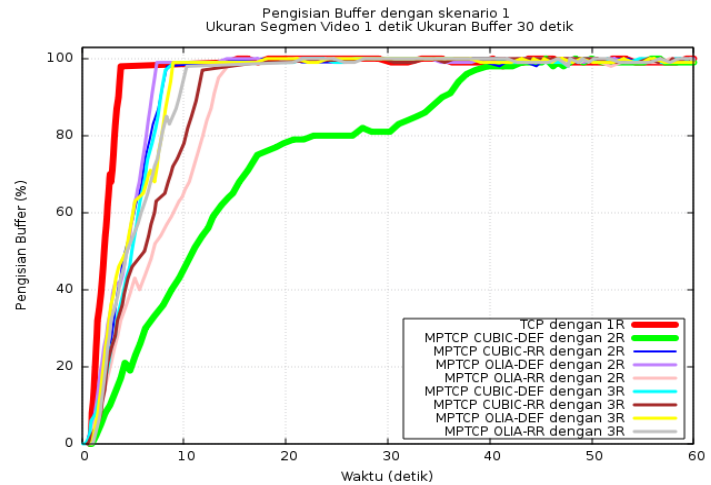

Gambar 10. Waktu pengisian buffer minimal

Meski demikian, waktu pengisian buffer minimal pada skenario 1 mengalami kondisi yang berbeda. Dimana pada percobaan menggunakan TCP, waktu pengisian buffer minimal lebih cepat diantara semua percobaan yang lain.

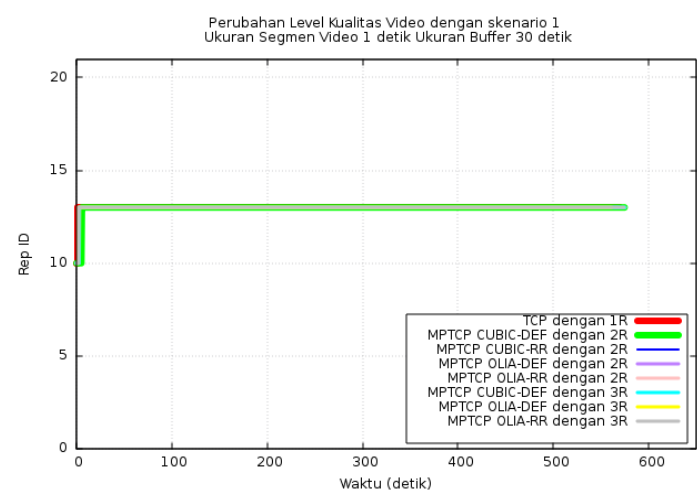

Gambar 11. Perubahan Level Kualitas dengan skenario 1

Pada skenario 1, dengan bandwidth stabil, satu satunya perubahan level yang terjadi adalah saat meminta file MPD sebagai awal dari semua proses streaming, dimana nilai level yang diminta adalah level terendah pada ukuran resolusi 1280x720. Kemudian segmen berikutnya meningkat dan stabil diangka yang sama sampai akhir percobaan.

\subsection{Skenario 2 menggunakan bandwidth tidak stabil}

Skenario 2 diujikan dengan kondisi bandwidth tidak stabil dimana bandwidth pada traffic shapping pada masing-masing 
jalur mengalami kondisi naik dan turun. Pada skenario ini tampak ada beberapa hal yang perlu dicermati. Penggunaan TCP pada skenario 2 pengisian buffer terus menurun sampai sangat kecil pada saat kondisi bandwidth tersedia mengalami penurunan. Hal ini menyebabkan pemutar video mengalami stall dan tidak dapat meneruskan memutar video karena jumlah minimal pengisian buffer tidak tercapai. Namun pada pemutar video dengan multi jalur, pengisian buffer dapat berlangsung dengan baik. Meski kondisi jaringan berubah-ubah, tetap dapat memasok paket data yang dibutuhkan sesuai dengan waktunya. Tidak ada perbedaan signifikan dalam penggunaan dua jalur ataupun tiga jalur. Kondisi ini ditampilkan dalam Gambar 12.

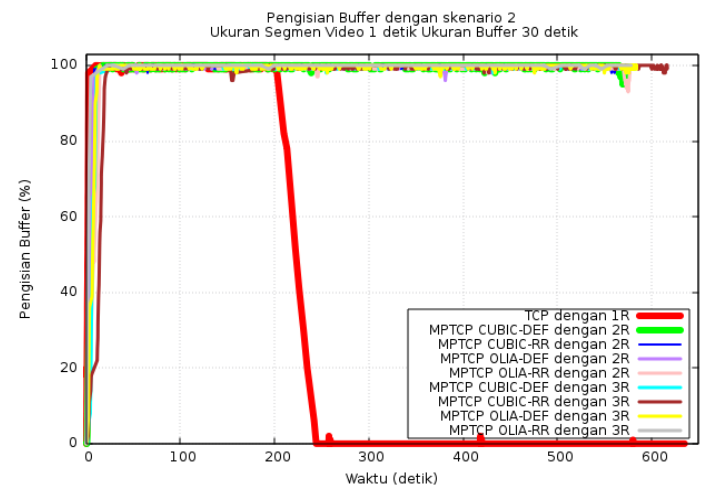

Gambar 12. Pengisian buffer dengan skenario 2

Meski demikian, TCP tetap memiliki waktu pengisian buffer minimal paling baik diantara semua percobaan yang ada. Sehingga pemutar video dapat lebih cepat memutar video saat jumlah paket data sudah mengisi 30 persen dari kuota buffer yang ada. Percobaan dengan multi jalur memanfaatkan paralel TCP pada pengendali kongesti CUBIC, mengalami waktu terpanjang dalam penantian pemutaran video. Hal ini dikarenakan mekanisme pengendali kongesti TCP reguler yang tidak memungkinkan pemindahan jalur seperti pada mekanisme OLIA. Hal ini ditunjukkan dalam Gambar 13.

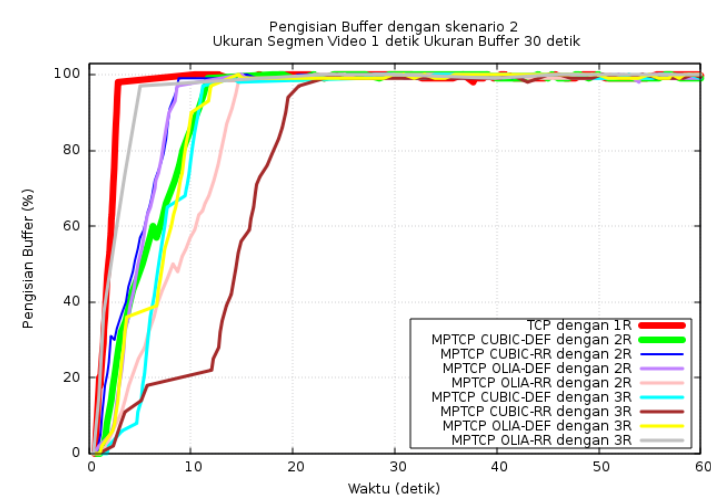

Gambar 13. Waktu pengisian buffer minimal dengan skenario 2

Percobaan dengan menggunakan skenario 2 menghasilkan perubahan level kualitas yang sama untuk percobaan dengan dua dan tiga jalur. Namun pada percobaan dengan satu jalur menggunakan TCP, terjadi penurunan level kualitas saat kondisi jaringan memburuk. Dan terus demikian sampai akhir percobaan. Hal ini ditunjukkan dalam Gambar 14.

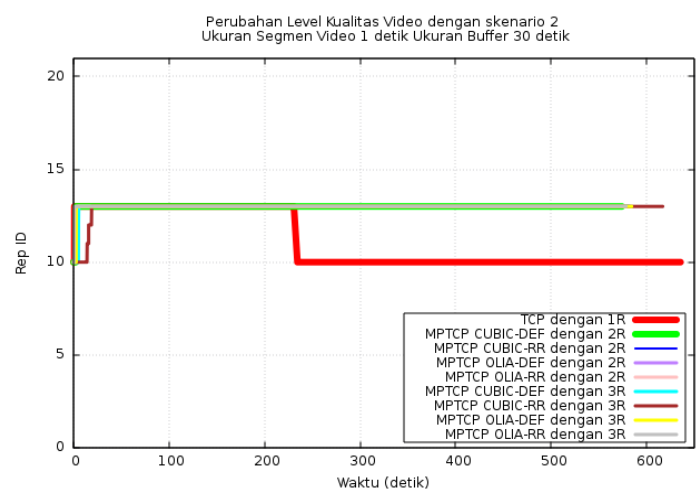

Gambar 14. Perubahan Level Kualitas dengan Skenario 2

\subsection{Skenario 3 menggunakan bandwidth anak tangga}

Skenario 3 diujikan dengan kondisi bandwidth tersedia menyerupai anak tangga. Pada skenario ini, bandwidth yang tersedia untuk konfigurasi infrastruktur 1 mengalami penurunan sampai level minimal 500 kbps. Dengan demikian pengisian buffer pun mengalami penurunan sangat signifikan. Namun demikian, TCP sudah mengalami degradasi sejak penurunan ketersediaan 
bandwidth yang pertama terjadi, dan tidak membaik kemudian. Input pada buffer tidak lebih dari 5 persen sampai akhir percobaan. Penggunaan multi jalur tetap memiliki kemampuan bertahan lebih baik. Ditandai dengan stabilnya input buffer sehingga capaian pengisian buffer tetap stabil antara 90-100 persen setiap waktunya. Hal ini ditunjukkan dalam Gambar 15.

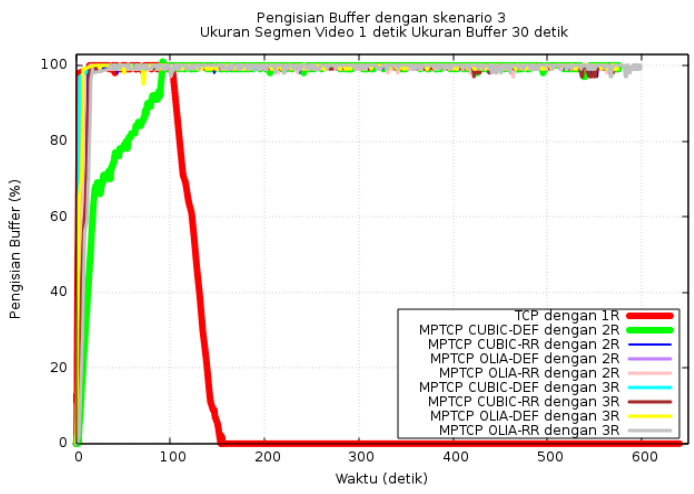

Gambar 15. Pengisian buffer dengan skenario 3

Namun demikian, percobaan dengan skenario 3 tetap menunjukkan bahwa waktu pengisian buffer minimal terbaik tetap diperoleh pada pemutar video dengan 1 jalur bila dibandingkan dengan pemutar video dengan multi jalur. Hal ini tampak dalam Gambar 16, TCP mampu mengisi buffer dan mencapai nilai 30 persen dari kapasitas kurang dari 5 detik. Sementara pada pemutar video dengan multi jalur, semakin banyak jalur yang dimiliki, maka pengisian buffer lebih cepat terisi, penggunaan algoritma penjadwalan default menghasilkan waktu pemutaran awal lebih cepat dibandingkan dengan penjadwalan round robin. Sementara itu penggunaan mekanisme pengendali kongesti OLIA memberikan waktu lebih baik dibandingkan dengan paralel TCP menggunakan CUBIC. Hal ini ditunjukkan dalam Gambar 16.

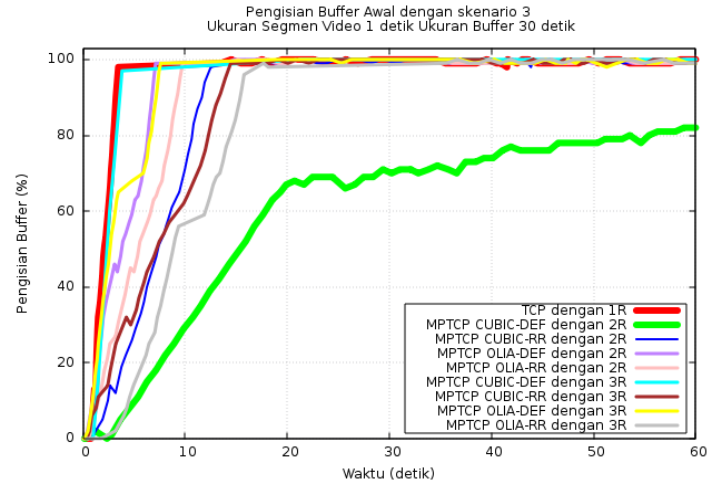

Gambar 16. Waktu pengisian buffer minimal dengan skenario 3

Dalam perubahan level kualitas, skenario 3 menghasilkan beberapa hal yang berbeda dibandingkan dengan skenario lain. Pada skenario ini, TCP tetap tidak dapat memperbaiki kondisinya setelah mengalami perubahan kualitas yang pertama kali. Penggunaan multi jalur sangat menolong dalam skenario ini, dimana pasokan paket data dapat terus terjaga. Kualitas dapat dipertahankan sehingga tidak perlu mengalami naik turunnya kualitas. Hal ini ditunjukkan dalam Gambar 17.

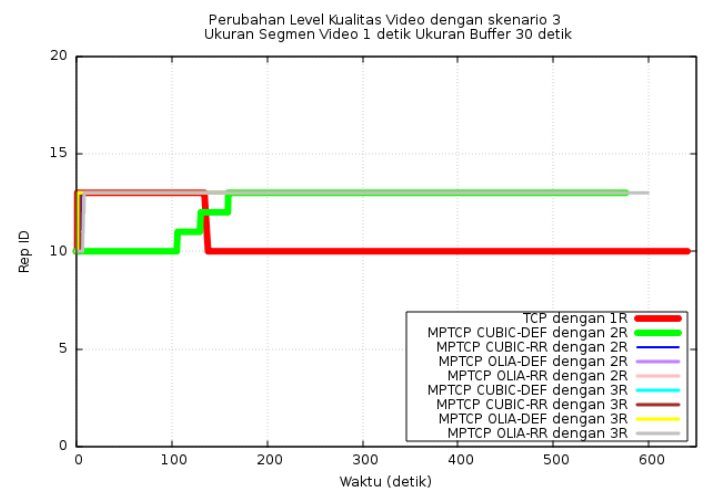

Gambar 17. Perubahan Level Kualitas dengan skenario 3

\section{Kesimpulan}

Dari pembahasan ini dapat disimpulkan bahwa

1. Dibandingkan dengan video dengan koneksi TCP, video yang dijalankan dengan Multipath TCP memberikan efek lebih baik pada waktu unduh per sequence 
dari segmen video yang diakses dari server terutama pada waktu ketersediaan bandwidth mengalami perubahan yang cukup signifikan seperti pada skenario 2 dan 3. Penggunaan buffer player juga demikian, saat skenario 1, TCP mampu mempertahankan level penggunaan buffernya sebaik yang digunakan MPTCP. Namun saat bandwidth bervariasi, terlihat bahwa TCP, cenderung menurun level penggunaan buffernya mengikuti ketersediaan bandwidth.

2. Jenis congestion control yang dipergunakan, tidak terlalu berpengaruh terhadap pengisian buffer pada pemutaran video adaptif. Hasil yang diperoleh memiliki nilai kemiripan satu sama lain. Meski demikian LIA memberikan nilai pengisian buffer dan waktu download yang lebih baik dibandingkan menggunakan CUBIC

3. Pada ukuran file 1 detik, Jenis Scheduler default yang ada pada kernel MPTCP menghasilkan waktu unduh yang lebih kecil daripada menggunakan Round robin, namun pada ukuran file yang lebih besar, round robin memberikan waktu yang lebih baik daripada scheduler default.

\section{Daftar Pustaka}

[1] CiscoVisual Networking Index diakses di

http://www.cisco.com/c/m/en_us/solut ions/service-provider/vni-forecast-

highlights.html. Tanggal akses 16 Januari 2016

[2] J. R. Iyengar, P. D. Amer, and R. Stewart, "Concurrent Multipath Transfer Using SCTP Multihoming Over Independent End-to-End Paths," JurnalIEEEACM Trans. Netw., vol. 14, no. 5, Halaman. 951-964,. 2006.

[3] S. Barré, C. Paasch, and O. Bonaventure, "MultiPath TCP: From Theory to Practice," in NETWORKING 2011, J. DomingoPascual, P. Manzoni, S. Palazzo, A.
Pont, and C. Scoglio, Eds. Springer Berlin Heidelberg, 2011, Halaman. 444-457.

[4] M. Handley, C. Raiciu, A. Ford, J. Iyengar, and S. Barre, "Architectural Guidelines for Multipath TCP Development," RFC 6182 Architectural Guidelines for Multipath TCP Development, Mar-2011. URL: http://tools.ietf.org/html/rfc6182.

Diakses 3 Maret 2014

[5] M. Handley, O. Bonaventure, C. Raiciu, and A. Ford, "TCP Extensions for Multipath Operation with Multiple Addresses," RFC 6824 - TCP Extension for Multipath Operation with Multiple Addresses, Jan-2013. URL: http://tools.ietf.org/html/rfc6824.

Diakses 28 Januari 2014

[6] M. Handley, C. Raiciu, and D. Wischik, "Coupled Congestion Control for Multipath Transport Protocols."

URL:https://tools.ietf.org/html/rfc635

[7] "Big Buck Bunny." .

[8] S. Lederer, C. Müller, and C. Timmerer, "Dynamic Adaptive Streaming over HTTP Dataset," in Proceedings of the 3rd Multimedia Systems Conference, New York, NY, USA, 2012, pp. 89-94.

[9] "VideoLAN - Official page for VLC media player, the Open Source video framework!" [Online]. URL: http://www.videolan.org/vlc/index.htm 1 .

[10] C. Müller and C. Timmerer, "A VLC Media Player Plugin Enabling Dynamic Adaptive Streaming over HTTP," in Proceedings of the 19th ACM International Conference on Multimedia, New York, NY, USA, 2011, halaman. 723-726.

[11] "VirtualBox - Oracle VM VirtualBox." [Online]. URL https://www.virtualbox.org/wiki/Virtu alBox. 
[12] "Vagrant by HashiCorp." [Online]. URL: https://www.vagrantup.com/.

[13] "MultiPath TCP - Linux Kernel implementation: Main - Home Page browse.’URL: https://www.multipathtcp.org/.

[14] J. Kovacevic, G. Miljkovic, V. Mihic, and K. Lazic, "Advanced rate adaptation algorithm in video streaming over HTTP," prosiding dalam 2014 IEEE Fourth International Conference on Consumer Electronics Berlin (ICCE-Berlin), 2014, halaman. 78-82. 